read more about 'national taxes for international purposes', 'global taxes', 'subsidy payments for tropical-forest countries', and the like. We know the ark is sinking, but we want to know how best to keep it floating a little longer. Norman Myers is a good adviser but seems exhausted at this stage of his 284-page book and is at his peak when describing the problems.

On style he is relentless, pouring out facts, having little change in pace, and using long words rather than the short ones (which Churchill said were better, the shortest being best of all). However the facts are here for us, most breathlessly. It is good to have such a compendium, both of information and of argument, all packaged for our use.

ANTHONY SMITH

\title{
The Wandering Gorillas, by Alan Goodall. Collins, £6.50.
}

Well-written, entertaining, even at times exciting, this book is a good buy for anyone who wants to know about the frustrations and joys of studying wildlife in Africa. Its difference from other such accounts is that those who study gorillas do so on foot, not from a Land Rover. A gorilla-watcher meets the animals on their terms, not his, and this book portrays well the awe and utter delight that a person feels as, alone and unarmed, he comes finally to be accepted by the totally wild gorillas that he is studying.

You will not, however, find much about gorilla social behaviour here - about the close bonds between the leading male and his females, the gentleness with which older youngsters play with small infants, or about the strong ties between a gorilla mother and her offspring, even into adulthood of the offspring. Only the last two of the book's 15 chapters are devoted to telling us about the gorillas themselves, as opposed to the author's experiences during his two years with them. These two chapters give an account of the gorillas' feeding and ranging behaviour - the author's particular subjects of study - of their future, and of what we should do to conserve them and their ever-dwindling forest habitat.

In countries like Rwanda, where population pressures are so great and natural resources so scarce, the Government has far more to worry about than the fate of a few gorillas. If these magnificent animals and the forests in which they live are to be saved, international help is needed. I have only one major criticism of the book and that is that the publishers have gratuitously resurrected the old 19th century Du Chaillu image of the vicious gorilla. The front-cover picture and three of the book's six colour plates depict charging, screaming gorillas, mouth open and canines bared. The author, with his obvious love of the animals, should not have permitted this blatant sensationalism.

A. H. HARCOURT

\section{The Breakdown and Restoration of Ecosystems, edited by M.W. Holdgate and M.J. Woodman. Plenum Press, $\$ 36$.}

This is the third volume to be published in a series of conference reports on ecological topics under the rather surprising umbrella of NATO. This conference was held in Reykjavik in 1976, when it was known as the Conference on the Rehabilitation of Severely Damaged Land and Freshwater Ecosystems in Temperate Zones; the original title, if cumbersome, is somewhat more accurate. The volume contains 24 papers and various introductions, conclusions, and verbatim discussions, which would have benefited from more active editing. In particular the discussions show a disconcerting degree of precognition amongst the participants: in discussing both Parkinson's and Bradshaw's papers, speakers refer to subsequent papers.

The volume opens with a section on 'Basic Ecological Principles', which serves to demonstrate how far ecology is from understanding the operation of whole ecosystems, despite recent advances. The modern approach to single-species population dynamics is well summarised by R.M. May, but a very long paper by G.M. Van Dyne and others, on models for grazed ecosystem management, clearly provoked considerable discussion at the meeting, on the question of both cost and general applicability. J.N. Jeffers, in a 
thoughtful article, criticises such 'whole system' models, on the grounds that they tend to expand indefinitely as new research identifies further controlling or important ecosystem components. The second section is on 'Degradation of Land and Freshwater Ecosystems', both from a historical standpoint, using pollen analysis (E.W. Dimbleby), and using more recent examples. It makes somewhat depressing reading.

The meat of the volume lies in Section III, on the Restoration of Degraded Ecosystems. The importance of soil conservation and the restoration of soil fertility are stressed by several contributors, and there are four papers on problems, particularly of acidification, in fresh waters. Finally several writers consider the interface between ecology and planning.

Advances in science are now so rapid that individuals cannot keep pace, so that the day when one person could bring together a mass of information coherently seems to be passing. After reading much of these 500 pages I feel stimulated by many individual points, but I do not see any clear message emerging. The final discussion, again reported verbatim, is somewhat aphoristic and suggests that the participants may have shared my feeling. I turned to the final conclusions by $M$.W. Holdgate, hopefully, but found more a summary of the points already presented in the papers. This book is a useful source for much information on particular instances of ecosystem degradation and restoration, but it is not a definitive treatment.

ALASTAIR FITTER

The Terrestrial Ecology of Aldabra, edited by D.R. Stoddart and T.S. Westoll. Royal Society, $£ 21$ (incl. p\&p).

\section{The Ephemeral Islands: a Natural History of the Bahamas, by David G.} Campbell. Macmillan, £5.

Aldabra was first a cause celèbre of island conservation in 1874 when Darwin and other eminent scientists petitioned the Governor of Mauritius (then in charge) to protect the giant tortoises. Over the next century the atoll did little more than occasionally ripple scientific consciences, until the British Government's plan in the middle 1960s to build an airfield catapulted the Royal Society into first a major biological expedition, and then, the airfield abandoned, into a long-term study of the island's ecology. This is the second book arising out of recent interest in the island, the other being Tony Beamish's popular account published in 1970, and there has been a wealth of scientific papers. Two major symposia have been held by the Royal Society, and this book, reprinted from the Philosophical Transactions, is the published proceedings of the second of these, held in March 1977. It is not, as implied by the title, a complete review of the island's ecology. Many of the papers are useful reviews of aspects of the climate, geology and biology, the tortoises coming off best, but there is no synthesis, and nothing, for instance, on lizards, bats, snails, or the few introduced animals (rats, cats, pigs) which affect the otherwise virgin ecosystem. For the general reader Beamish's is still the only useful book on the island, but Aldabra connoisseurs and other students of island ecology will certainly need to consult this substantial addition to an already bulging portfolio of publications on the atoll.

The Ephemeral Islands is a very different kind of book, written by a biologist and conservationist with 25 years experience in the Bahamas as an introduction to the wildlife, plant and animal, of these Caribbean islands. David Campbell deftly covers a lot of ground in a short, well-illustrated book, with enough detail to satisfy not only the Bahamian public and tourists, but also the enquiries of an island biologist exploring a new area, who will find the bibliography and index invaluable as well.

Campbell briefly laments the total loss of the Caribbean monk seal and describes what has survived. With so many islands most of the fauna have been able to hang on somewhere or other, though the endemic hutia is confined to a 1000-acre islet, certain lizards likewise, and the formerly widespread whistling ducks, parrots, pigeons and flamingos now have drastically reduced ranges. Unwise introductions, as usual, are 